\title{
Women working in animal husbandry: a study in the agroecological transition context
}

\section{Eduarda Lopes Ferreira ${ }^{1}$ (D) Rodrigo Alves Barros ${ }^{2}$ (D) Paula Dias Bevilacqua ${ }^{3^{*}}$ (D)}

${ }^{1}$ Departamento de Veterinária, Universidade Federal de Viçosa (UFV), Viçosa, MG, Brasil.

${ }^{2}$ Departamento de Veterinária, Programa de Pós-graduação em Medicina Veterinária, Universidade Federal de Viçosa (UFV), Viçosa, MG, Brasil.

${ }^{3}$ Departamento de Veterinária, Programa de Pós-graduação em Medicina Veterinária, Universidade Federal de Viçosa (UFV), 36570900, Viçosa, MG, Brasil. E-mail: paula@ufv.br. "Corresponding author.

ABSTRACT: This study investigated the engagement of women in animal husbandry in agroecological transitions scenarios and reflects on the advancements and challenges encountered in overcoming gender inequalities in rural areas. Semi-structured interviews and participant observation were conducted in nine properties in three municipalities in the region of Zona da Mata of Minas Gerais State. Women are involved in husbandry of different animal species, and participate in the management, processing, and marketing of products, contributing to food diversification, self-consumption, and income generation. Overcoming gender inequality in an agroecological scenario requires making the work and knowledge of women farmers visible and increasing their prominence, while ensuring economic valuation of their work and access to the market through public policies aligned with the reality of animal production in agroecological family agriculture contexts.

Key words: sexual division of labor, family farming, feminist economy, public policies.

Mulheres e trabalho na criação animal em contexto de transição agroecológica

RESUMO: Investigou-se a participação das mulheres nas práticas de criação animal em contextos de transição agroecológica, refletindo sobre os avanços e desafios na superação das desigualdades de gênero no meio rural. Realizaram-se entrevistas semiestruturadas e observação participante em nove propriedades de três municípios da Zona da Mata Mineira. As mulheres atuam na criação de diferentes espécies animais, participando do manejo, processamento e comercialização de produtos, contribuindo para diversificação dos alimentos, autoconsumo e geração de renda. A superação das desigualdades de gênero no contexto da agroecologia implica na visibilização do trabalho, conhecimento e protagonismo da agricultora, com a valorização econômica e acesso ao mercado através de politicas públicas coerentes com a realidade da produção animal na agricultura familiar agroecológica.

Palavras-chave: divisão sexual do trabalho, agricultura familiar, economia feminista, políticas públicas.

\section{INTRODUCTION}

Women farmers are not only responsible for the maintenance and reproduction of the family nucleus and domestic work, but also work in agriculture and are responsible for the "backyard," where they carry out agricultural activities (mainly vegetable gardens, small fields, and food processing) and care for animals (especially small animals), contributing significantly to the survival and productivity of the family group (PAULILO, 2004; HEREDIA \& CINTRÃO, 2006). However, family farming and rural women have been historically left on the sidelines of public policies fostering rural development in Brazil.
The National Policy of Agroecology and Organic Production (Política Nacional de Agroecologia e Produção Orgânica - PNAPO), launched in 2012, instituted ecological and organic agriculture as the basis for rural development in Brazil (BRASIL, 2012). Agroecology is more than a production technique: it represents a paradigm shift in which the integration of scientific knowledge from different fields with traditional (or peasant) knowledge is used to critique and overcome the capitalist mode of production, which is materialized as industrial agriculture in the rural environment (ALTIERI, 2004; CAPORAL \& AZEVEDO, 2011). Families in this study are investigated in the midst of an agroecological transition, which is understood as a gradual process 
of transformation from a "conventional" productive model to a production system that prioritizes the use of the family's own material and intellectual resources, with the aim of enhancing the autonomy of farming family (CAPORAL \& AZEVEDO, 2011).

The PNAPO incorporates a gendersensitive approach, and aims to reduce gender inequality and promote the economic autonomy of women (BRASIL, 2012). At least from a theoretical perspective, agroecological principles based on the emancipatory action of farmers show that equity in gender relations is an essential condition for the sustainability of agroecological production and citizenship in the field (PACHECO, 2009; SILIPRANDI, 2015). The incorporation of gender in public policies (of an international nature) was initiated in the 1990s. It was influenced by the feminist movement that operated in different countries and international organizations, and encompassed several demands. As pointed out by NOBRE (2016), although the strategy of mainstreaming gender in public policies is an advancement, it is not enough, and can 'tame' the radicality of the feminist and women's movement, especially when it suggests "the structure of human rights as a reference for the agenda of these movements." The appropriation of the discourse of human rights can impoverish the many agendas of the movements, in favor of the construction of a consensus, and, because of its universalizing character, it can cover up the interests of capitalist accumulation (NOBRE, 2016). Thus, the operationalization of the concept of gender and different possible feminist approaches aligned with the theoretical postulates of agroecology continues to operate as a challenge for academic and/or social movements (SILIPRANDI, 2018).

According to LOPES NETO et al. (2015), the systematizations of the productive work of women in agroecosystems are still rare, and when they do exist, they usually emphasize the performance of men or families without giving due prominence to women. Given the challenges mentioned above and the few studies on animal husbandry in the agroecological transition context, we investigated the participation of women in animal husbandry and reflected on the advancements and challenges encountered in overcoming gender inequalities in rural areas and agroecological production.

\section{MATERIALS AND METHODS}

This study was conducted on family farming properties in the midst of an agroecological transition in the municipalities of Viçosa, Muriaé, and Pedra Dourada, in Zona da Mata of Minas Gerais State. The sites under study were defined and the participants were chosen through a partnership with an extension group, called "Animals for Agroecology," at the Federal University of Viçosa, and the Center for Alternative Technologies at Zona da Mata (Centro de Tecnologias Alternativas da Zona da Mata - CTA-ZM); both groups have a consolidated role in strengthening agroecology in Zona da Mata Mineira. Partnerships with other organizations such as Cooperative of Solidarity Family Farming Producers (Cooperativa dos Produtores da Agricultura Familiar Solidária - COOPAF - Muriaé) and Raízes da Mata Agroecological Network of Prosumers (Viçosa), were also essential in this study. These organizations were created to market the agroecological produce of local family agriculture through their food markets on a weekly basis.

The investigation was guided by the theoretical and methodological assumptions of Qualitative Research, which focuses on the meanings and intentionality of actions in the context of social structures (MINAYO, 2010). Semi-structured interviews and participant observation were chosen as instruments to address the themes of animal husbandry (species, quantity, and management), the production of animal products (AP), and the perception of the division of labor between men and women in the property.

The sample size was defined by theoretical saturation (MINAYO, 2010), in which data collection is interrupted when speeches and opinions become recurrent, among other observations. The investigation was conducted between January and July 2016, and covered nine properties, five of which were in Muriaé, three in Viçosa, and one in Pedra Dourada. The interviews were recorded. Due notice was given to and prior authorization was received from the interviewees, who signed Informed Consent Forms (ICF) to indicate their willingness to participate. Field notebooks were used as support material at all times during the study. The reports and records obtained from the interviews and participant observation were subject to thematic content analysis (BARDIN, 2011).

\section{RESULTS}

Characterization of families and animal husbandry

Families in this study comprised couples aged over 40 years. Some were retired, with adult children living elsewhere. One family 
comprised a young couple with a newborn child. The other three families had children and young adults who continued to live at home.

Considering the technical elements involved in agroecological production, the properties in Muriaé and Viçosa were considered to be in a state of "agroecological transition" because some farmers continued to use agrochemicals in plant management and in the treatment of animals (mainly ecto and endoparasiticides), and were dependent, to some extent, on inputs that were external to the property (seeds and raw material for rations, among others).These aspects were more frequent in Muriaé. The property in Pedra Dourada was considered agroecological because of the complex interactions between the family and the components of the agroecosystem such as animals, vegetables, soil, and water, thus producing a system of cooperation and feedback and enabling the organic production of food using their own resources.

All properties had chickens, and only one did not raise dairy cattle. Pigs, fish, and bees were raised in four, three, and one of the properties, respectively. The main economic activity of the families was milk production in Muriaé and the production of vegetables and eggs in Viçosa. The surplus milk production in Viçosa was eventually destined for sale, complementing the family income. Several AP were produced for self-consumption and/or sale, including meat (poultry and pigs), eggs, honey, milk, and derivatives. The AP were also used for the preparation of quitandas (small groceries) and were eventually sold directly or in food markets. In all properties, animal husbandry was mainly aimed at self-consumption (Table 1).

\section{Division of labor in the field of animal husbandry}

In all families, the activity of raising chickens was considered a woman's responsibility, with the tasks ranging from chick management, feeding, and sanitation, to egg collection, the cleaning of the facilities and the nest, and the use of products (egg and meat). Men performed such tasks when women were not on the property.

In all families, cattle ranching were perceived as a man's responsibility, with the tasks ranging from the management of animals (on pasture and the corral), feeding, and milking, to the administration of allopathic medicines and vaccines, and the maintenance of fences and facilities. In one family, the woman also participated in milking and in handling health and food management activities. In four families, women participated in tasks out in the field, such as changing the grazing animals and separating the calves and placing them to suckle. Milk preparation (boiling, straining, and storage) and the production of derivatives were considered as activities exclusively for women. Activities that involved 'caring' for the health of the animals and, more specifically, the use of natural therapies (mainly herbal medicine) and/or homeopathy were also seen as the responsibility of women. As woman farmer 8 said, "When I worked with him there, I did a lot of [natural treatment]... I used tea, I prepared baths... and the medicinal plants..."

In two families, men were responsible for all tasks related to pig raising, and in the other two, they were divided between the couple. In the family in which fish farming was the main source of income, the man managed the production, deciding on the purchase or sale of fish and inputs and technical aspects of animal management, and the woman participated in the selection of fish, feeding, cleaning of facilities, and preparation of animals for sale. When it came to beekeeping, women cleaned, coated, and bottled the honey, all of which were carried out at home. The man handled the hives in the field (harvesting the combs, extracting the honey, and handling the wax). The work with animals was often referred to as care, and the expression "I take care of animal husbandry" was commonly used, meaning that women performed all the tasks necessary for animal husbandry.

\section{Domestic work, 'productive'work, and other duties}

The interviewees generally reported that although the labor was divided equally between men and women, each performed specific activities. Women were responsible for domestic chores. In some situations, men claimed to perform housework, but only when women were absent from the property. The attribution of domestic work as women's work was justified as something traditional and 'cultural', transmitted by the ancestors. For instance, farmer 6 noted: “(...) I remember that my father always said that women do not even need to study; they just need to marry and cook!"

Men were generally responsible for the work that was considered 'productive', that is, work that generated income or work that constituted the main economic activity of the family. In all eight families, the participation of women in such activities was reported as a form of 'help'. For example, woman farmer 1 said, "When he plants something, I help him. On the day the calves are separated, I separate the calves later and arrest and change the grazing cows." Woman farmer 9 noted, "I guide the 
Table 1 - Characterization of interviewed families according to animal husbandry and product destination aspects, 2016.

\begin{tabular}{|c|c|c|c|c|}
\hline \multirow[t]{2}{*}{ FAMILY } & \multicolumn{2}{|c|}{ 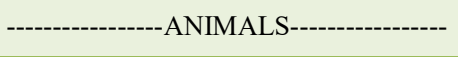 } & \multirow[t]{2}{*}{ PRODUCTS } & \multirow[t]{2}{*}{ DESTINATION } \\
\hline & SPECIES & $\mathrm{n}$ & & \\
\hline \multirow{6}{*}{ A } & \multirow{2}{*}{ CHICKEN } & \multirow{2}{*}{15} & Eggs & Self-consumption and sale \\
\hline & & & Meat & Self-consumption \\
\hline & \multirow{2}{*}{ CATTLE } & \multirow{2}{*}{6} & Milk & Self-consumption \\
\hline & & & Cheese & Self-consumption and sale \\
\hline & \multirow{2}{*}{ PIG } & \multirow{2}{*}{2} & Meat & Self-consumption \\
\hline & & & Piglets & Sale \\
\hline \multirow{5}{*}{ B } & \multirow{2}{*}{ CHICKEN } & \multirow{2}{*}{18} & Eggs & Self-consumption \\
\hline & & & Meat & Self-consumption \\
\hline & CATTLE & 2 & Milk & Self-consumption and sale ${ }^{2}$ \\
\hline & FISH & uncountable & Ornamental fish & Sale \\
\hline & BEE & uncountable & Honey & Sale \\
\hline \multirow{5}{*}{$\mathrm{C}$} & \multirow{2}{*}{ CHICKEN } & \multirow{2}{*}{30} & Eggs & Self-consumption and sale \\
\hline & & & Meat & Sale \\
\hline & CATTLE & 12 & Milk & Self-consumption and sale ${ }^{3}$ \\
\hline & PIG & 1 & Meat & Self-consumption \\
\hline & FISH & uncountable & Meat & Self-consumption \\
\hline \multirow{4}{*}{$\mathrm{D}$} & CHICKEN & 20 & Eggs & Self-consumption \\
\hline & \multirow{2}{*}{ CATTLE } & \multirow{2}{*}{8} & Milk & Self-consumption \\
\hline & & & Cheese & Sale \\
\hline & PIG & 1 & Meat & Self-consumption \\
\hline \multirow{5}{*}{$\mathrm{E}$} & \multirow{2}{*}{ CHICKEN } & \multirow{2}{*}{22} & Eggs & Sale \\
\hline & & & Meat & Self-consumption \\
\hline & \multirow{3}{*}{ CATTLE } & \multirow{3}{*}{4} & Manure $^{1}$ & Fertilizing \\
\hline & & & Milk & Self-consumption \\
\hline & & & Cheese & Self-consumption and sale \\
\hline & CHICKEN & & Eggs & Self-consumption \\
\hline $\mathrm{F}$ & CHICKEN & 25 & Meat & Self-consumption \\
\hline & PIG & 16 & Meat & Self-consumption \\
\hline & & & Eggs & Self-consumption \\
\hline G & CHICKEN & 30 & Meat & Self-consumption \\
\hline & CATTLE & 8 & Milk & Self-consumption and sale ${ }^{2}$ \\
\hline & & & Eggs & Self-consumption \\
\hline & CHICKEN & 15 & Meat & Self-consumption \\
\hline $\mathrm{H}$ & & & Milk & Self-consumption and sale ${ }^{2}$ \\
\hline & CATTLE & 15 & Cheese & Sale \\
\hline & FISH & uncountable & Meat & Self-consumption and sale \\
\hline & & & Eggs & Self-consumption \\
\hline & CHICKEN & 12 & Meat & Self-consumption \\
\hline I & & & Milk & Self-consumption and sale ${ }^{4}$ \\
\hline & CATTLE & 40 & Butter & Self-consumption and sale \\
\hline & & & Cheese & Self-consumption \\
\hline
\end{tabular}

Notes: 1 This family was the only one to mention manure; although, in general the farmers use animal manure for fertilizing. 2 Milk delivery in expansion cooling tank for sale. 3 Milk delivery to middle men. 4 Milk delivery to local cooperative.

administration of medicine and tea. Then, I go there to help administer it, because sometimes, I have to hold [the cow]." Even when women participated in the main economic activity in the property, such as production of vegetables, the report showed a lesser valuation of their work. For example, woman farmer 4 reported, "If I take care of the vegetable garden, it is certain that nothing will be taken to the market. I just pick and 
wash everything and then put everything in the box for him. When he (...) takes it, I go to the vegetable garden again, and then collect and wash everything so that when he arrives at night, I can put them into the boxes for the next day. I do everything at this stage!"

The difference between the work of men and women appears in the reports as well. Woman farmer 3 noted, "(...) he works on things that sustain the home, and brings us money. I, who have not studied, have had no training, have never worked outside, so I help this way (referring to domestic work)." Sometimes, this perception was presented with some criticism. For example, woman farmer 3 said, “(...) in her case [referring to the daughter], who works outside, it is unfair that the husband does not help around the house, because both of them arrive home at the same time and when she arrives, she still has to take care of the house (...) I think this is inequality!" Sometimes, it is not accompanied with any criticism. For example, woman farmer 1 said, “(...) I think it is normal (laughs) (...) if the couple is married, I think the woman must help her husband, so I do not see any difference! No big deal, I think it is normal!"

Over half the women participated in the management of the accounts of the property, and some were solely responsible for this activity. Two of these women also participated in the management of production, deciding how, when, and where a plant and/or animal species would be produced, and participated in decisions on how to use and market the products. One of these women participated in the Raízes da Mata Network, where they were responsible for marketing all products from the property. The AP were marketed in short circuits such as at food markets (eggs and chickens both slaughtered and not slaughtered, and cheese), directly to interested parties (piglets, milk, cheese, butter, eggs, and chickens both slaughtered and not slaughtered), and/or in long circuits, with milk being delivered to middlemen, cooperatives, or expansion milk cooling tanks. Food markets included open-air ones located in the municipalities, or, in the case of Viçosa, they also included the Raizes da Mata Network food market.

There were several reports of interruption in the production of milk derivatives, such as cheese, butter, and curd, and even of the direct sale of milk, as a result of difficulties in marketing because of the restrictive requirements of prevailing legislation. The strictness of legislation governing the marketing of eggs and poultry was also mentioned. For example, women farmer 5 said, "I intend to increase our egg production, it is not difficult to produce, but sanitary surveillance is a bit strict, even for eggs, requiring the preparation of nests and administration of vaccines!" and farmer 5 said " $(.$.$) chicken meat (...) when there is$ demand, is also sold (...) I have sold much chicken at the food market ... but now with these requirements...".

We observed that most women participated actively in local trade unions and some assumed leadership positions as well. One of the women also participated in the local cooperative and was the leader of the church committee in the community.

\section{DISCUSSION}

Women's work in animal husbandry is essential in agroecological transitions, both in terms of the quantity and variety of tasks performed (daily management of animals, and production of food for livestock and medicinal plants for treatment and prevention of diseases, among others) and/or in terms of the transformation and marketing of APs. These aspects may suggest an alignment with the agroecological assumptions, in which the participation of women is seen as essential to ensure a rupture in the hegemonic model of production, thus aiming at the autonomy of the farming family, according to CAPORAL \& AZEVEDO (2011). SILIPRANDI (2002, p.108) pointed out the need to problematize the ideology of "monolithic, harmonious, and balanced families" while reflecting on rural realities. Feminist economies also problematize the altruistic family, an institution without conflict, where harmony reigns and; consequently, the inequalities among its members remain hidden (MUNOZ, 2014). In this sense, the agroecological family needs to be 'observed' while avoiding the easy path of romanticization and idealization, thus implying the non-identification of conflicts and ruptures, which can be understood as potential ways of overcoming inequalities.

The work of women in animal husbandry in agroecological transition scenarios is invisible to some extent. This is expressed in the interviews, when the women themselves referred to their work as 'help', and when they did not recognize their work as productive activities because what they did was partly intended for self-consumption. Invisible work, understood as work that is unpaid and not intended for profit (CARRASCO, 2014), leads to the devaluation of rural women's work. This has been addressed extensively in different studies (PAULILO, 2004; SALES, 2007). This devaluation is rooted in the process of modernization of agriculture, which demarcates the sexual division of labor in family farming by assigning the productive sphere to men with a strong sense of additional social value, and by 
assigning the reproductive sphere to women, with lower value (KERGOAT, 2002).

Animal husbandry work (mainly small animals) takes place in the 'backyard' space, which is close to the house. Animal husbandry is understood as a type of 'care' that is seen as similar to the tasks of raising and caring for children, the sick, and the elderly. These two factors promote the (re) production of a natural/maternal connotation to work with animals. Studies conducted, including in agroecological scenarios, have recognized the backyard and surroundings of the house as important places for family (re)production and female empowerment (SALES, 2005; LOPES NETO et al., 2015) and make the participation of women in animal husbandry more evident (FAO, 2011).

Thus, the backyard operates as a double place of care: that of the naturalized care of animals, an extension of 'maternity'; and that of an activity that provides sustenance, well-being, and quality of life for the family. The latter, according to SALES (2005), is embodied in the fact that 'small-scale husbandry' contributes significantly to food security, in the family economy and in strengthening sustainable agriculture. In the family economy, in addition to being a source of income, animals constitute strategic savings. In strengthening sustainable agriculture, the manure produced contributes to the continuity of soil nutrient cycles and to the reduction in the use of chemical inputs in plant production.

The design of sustainable agroecosystems is an important aspect that outlines the principles of agroecology (ALTIERI, 2004).This is perhaps its most important technical component. In this sense, the backyards and small animal husbandry practices there seem to comply fully with this principle. However, although the backyard is a potential place for the economic empowerment of women, it appears to be the place in which they are imprisoned to their historical gender roles since the organization of the space around the house is not arbitrary, but is rather defined to reconcile domestic work with the work that is carried out in the backyard. This is currently under discussion among feminist theorists, because, according to FERREIRA \& MATTOS (2017), we tend to look at the theme of productive backyards with suspicion as they are perceived as an extension of domestic work.

Conversely, no interview indicated that the care of animals (carried out in backyards) is the responsibility of the women alone. Apparently, this task is understood as theirs, thus leading to the perception that their subjection to this work is natural. Therefore, we question whether being in the backyard and caring for the animals would be a choice or an imposition. Despite the efforts to make the work carried out in backyards visible, in order to imply the empowerment of women because they are economically important spaces (SALES, 2005; LOPES NETO et al., 2015), it appears that this does not change the sexist dynamics of organization and perception of spaces in properties, even in the context of an agroecological transition. That is, backyards, although productive, remain within the surroundings of the houses, and are associated with the domestic space and/or the conciliation of women's tasks there, since there is a strong perception that domestic work is the sole responsibility of women.

The notion that sexual spaces are essential for the incorporation of the gender debate in agroecology was pointed out by SILIPRANDI $(2018$, p.5), since "the redesign of agroecosystems must consider the gender dimensions." The spatial organizations found in the properties investigated, represented by the division of labor between the backyards and other places, do not escape this rule; on the one hand, pushing the man farmer away and, on the other, bringing the woman farmer closer to the surroundings of the house and the domestic environment. However, the responses of the women farmers suggest that they have a broader perception of the property, because they share responsibilities with men in other productive spaces in several cases, which does not occur in work that is specifically attributed to women.

We base our reflection on the understanding of animal husbandry as 'care' in line with BORIS (2014, p.103), which comprised the understanding of "care as a component of reproductive work that is not equivalent to domestic work but is usually performed together." According to BORIS (2014), the struggle for care to be considered work and to be remunerated represents the search for respect and dignity for people who perform domestic work, and care workers should share the language of production to generate visibility and add value to their work. This does not imply the adoption of the traditional economic concept that has an androcentric bias as pointed out by CARRASCO (2014), but rather implies the incorporation of an alternative economic theory proposed by feminism, which not only allows a joint analysis of production and reproduction, but places social reproduction as the central axis of the socioeconomic system, which would then result in the understanding and valuation of activities involving care, affection, and interdependence, which are commonly performed by women (BORIS, 2014; CARRASCO, 2014). 
Based on this and considering that care includes experiences of intra- and inter-specific relationships, caring for animals refers to the act of women farmers undertaking a daily, intense, and diverse physical, cognitive, and emotional effort, similar to what is expected of them when they care for children, elderly, and/or disabled people. In addition to the moral commitment to deal with lives (human and animal) and to ensure their well-being, they produce their ethics since they are responsible for generating an important part of the resources necessary for this, that is, before preparing food for the family, they participate in the management of animals, the vegetable garden, and the field (which feeds the family and the farm), medicinal plants, soil, and water. To this end, they use not only their rationality for planning and making decisions, but also their affection. Economic value must be given to this work, which is based on a commitment to food security and health promotion, and is not solely in the interest of the market.

Thus, the care of animals by women can be understood as an additional 'value', to be even highlighted by agroecological production in terms of product identity and quality. Women rely on alternative practices in animal husbandry such as the use of unconventional therapies (homeopathy and herbal medicine) in the treatment of animals, as reported by some participants in this research.

Animal care as a site of experimentation for women and the meeting of agroecological principles (such as the non-use of chemicals and pesticides), enhances the advancement of knowledge on agroecological animal husbandry and makes women farmers prominent. In this regard, it is important to consider that despite the important advancements that science has brought to the construction of agroecological knowledge, scientific knowledge on animal breeding is still scarce, poorly systematized and even non-existent, depending on the animal species in focus. While animal husbandry has not been explored much by researchers and technicians in their scientific and technological development efforts, it is a frequent object of experimentation and knowledge production in agroecology, or more broadly, in family farming. As there are no technicians with training in agroecological animal husbandry, women farmers automatically become the experimenters and developers of 'new practices' in animal husbandry. To what extent would the lack of concern (or efforts) to systematize or develop scientific knowledge on agroecological animal husbandry be related to the fact that these practices are primarily developed by women? Although, this issue requires a detailed approach, what we want to emphasize is that the experience of women farmers has a lot to contribute to the advancement of knowledge on agroecological animal husbandry and that women's authorship of knowledge is guaranteed.

When it comes to the production and marketing of APs in Brazil, legal requirements, especially those related to the technical aspects of infrastructure (facilities and equipment), make it practically impossible to produce these products on small rural properties and to market them through family farming. Even the recently approved Law no. 13.680/2018, which calls for flexibility in the procedures for the registration of establishments and products, and requires inspections to be conducted in a guided manner in the case of handmade animal products, does not significantly change this situation. This is because this law contradicts itself, by saying that such procedures should follow Decree No. 9,013/2017, which is known to be restrictive and detailed.

Brazilian legal restrictions challenge not only the potential that this sector has to impact poverty reduction and food security positively, as indicated in the FAO (2009) report on animal husbandry, but also exclude from this productive sector a significant portion of those who produce these products, that is, family farming, and, more perversely, affect women farmers, since they are mainly responsible for processing and selling products. This highlights the greater degree of fragility of women in this process.

According to FERREIRA \& MATTOS (2017), the response of agroecology to feminist criticism resulted in demands for other things such as specific technical assistance for feminism and agroecology. A feminist perspective, that is, a perspective that considers female prominence in the production of these products, is necessary in formulating legislation on APs. This space is still characterized by capitalist industrial production. Thus, quality parameters used to evaluate and ensure the safety of products are strictly related to technical (production) and/or biological (of animals and their products) dimensions, which, by being validated by scientific knowledge, can only be achieved through industrial production. For example, legislation requires the absence of organisms that cause diseases in human beings in animal products, and this requirement is justified by the need to protect consumer health. The importance of legislation for guaranteeing health is not questioned here, that is, that the quality of products does not involve risks (or minimal risks, according to the most current 
debate) to the health of consumers. However, to what extent do the legal requirements fulfill more of an order of capitalist accumulation, production, and marketing than a commitment to public health? In SANTOS \& BEVILACQUA (2019), family farmers reported that their practices of manufacturing milk derivatives were more suitable for safer production and for providing better quality products when compared to dairy companies, because in addition to handling a smaller volume of milk, production is carried out by a single person. Therefore, the challenge is to produce quality indicators (of processes and finalists) that incorporate the dimension of care ethics from a woman's perspective.

The fact that several women are responsible for the 'accounts' or for even deciding on the productive aspects, demonstrates the active participation of women farmers in what have been historically considered as male tasks, being able to translate the achievement of autonomy and (re) positioning of roles, thus producing greater equality in relations between men and women in the field.

These transformations may partially result from the insertion of women in political spaces such as unions and collectives/women's movements, as observed among the women interviewed in this study. In these spaces, political education, which generally includes feminist debates and debates on gender relations, self-knowledge is produced and women are made aware that they develop productive activities that are similar to (or greater than) those of men, thus enabling the reconsideration of their relations, the perception of inequalities among men and women, and their desires for change, both in the family and social spheres (SALES, 2007; SILVA, 2012; SALVARO et al., 2013; SILIPRANDI, 2015). In Brazil, the process of induction and strengthening of these spaces within the scope of agroecology was fundamental to the formulation of the PNAPO which incorporates in its text the gender approach and the stimulus to the participation of women in collective organizations that act in the productive, social and, political spheres (BRASIL, 2012). This path articulates the feminist economy and the formulation of public policies from the social and feminist movements; it can be the answer to the challenge of "reducing inequalities without creating others (...), ensuring that people and sectors in subordinate positions in society can become the political subjects that reverse this subordination" (NOBRE, 2016, p.651). The socialization of women farmers in collective organizations can be an opportunity for the constitution of political subjects that can produce change from the inside out, thus making progress in the fight against oppression and gender inequalities in the countryside and breaking out culturally imposed standards for women.

\section{CONCLUSION}

Major inequalities continue to characterize the condition of rural women, even in contexts of agroecological production. Women's work in animal husbandry is of great significance because it involves dealing with different species and the performance of several activities toward mastering AP processing techniques and procedures. Women's work in this context is not valued or treated as productive, as it is seen as "help" and "care." The marketing of these products does not take place to its full potential since extremely restrictive legal aspects weigh down on this activity, which contributes to the invisibilization of women farmers' work. Thus, public policies that can value these products and legislation that is aligned with the practice of family farming can undoubtedly benefit rural workers and reduce inequalities.

Finally, there were advancements in relation to the technical aspects advocated by agroecological production such as the absence (or lesser use) of pesticides and reduced dependence on external inputs and increased food sovereignty. However, advancements in gender relations such as female exclusivity in the performance of domestic work continue to remain fragile areas. Gender equality is a major challenge in the promotion of the agroecological approach.

\section{ACKNOWLEDGEMENTS}

The authors thank the family farmers who kindly participated in the study. We thank the Fundação de Amparo à Pesquisa do Estado de Minas Gerais (FAPEMIG) (Processo CVZAPQ-03205-14), the Conselho Nacional de Desenvolvimento Científico e Tecnológico (CNPq) and PROEXT/MEC/SESu 2015 for their financial support to research and scholarships. This study was financed in part by the Coordenação de Aperfeiçoamento de Pessoal de Nível Superior - Brasil (CAPES) - Finance Code 001.

\section{BIOETHICS AND BIOSSECURITY COMMITTEE APPROVAL}

The research protocol was submitted to and approved by the Ethics Committee on Research with Human Beings of the Universidade Federal de Viçosa (Protocol No. 1.269.085).

\section{DECLARATION OF CONFLICT OF INTERESTS}

The authors declare no conflict of interest. The founding sponsors had no role in the design of the study; in the collection, analyses, or interpretation of data; in the writing of the manuscript, and in the decision to publish the results. 


\section{AUTHORS' CONTRIBUTIONS}

ELF e PDB conceived and designed the study; participated in analysis and interpretation of data, and in conception and writing of the manuscript. ELF conducted data collection and systematization. ELF, RAB e PDB critically revised the manuscript and approved final version.

\section{REFERENCES}

ALTIERI, M. Agroecologia: a dinâmica produtiva da agricultura sustentável. Porto Alegre: Editora da UFRGS, 2004. 120p.

BARDIN, L. Análise de conteúdo. Lisboa: Edições 70, 2011. 229p.

BORIS, E. Produção e reprodução, casa e trabalho. Tempo Social v.26, n.1, p.101-121, 2014. Available from: <http://www.revistas. usp.br/ts/article/view/84982>. Accessed: Feb. 08, 2019. doi: 10.1590/S0103-20702014000100008.

BRASIL. Decreto ${ }^{\circ} 7.794$, de 20 de agosto de 2012. Institui a Política Nacional de Agroecologia e Produção Orgânica. Diário Oficial da União, Brasília, DF, Brasília, DF, 21 ago. 2012 Seção 1, p. 4.

CAPORAL, F.R.; AZEVEDO, E.O. Princípios e perspectivas da agroecologia. Paraná: Instituto Federal de Educação, Ciência e Tecnologia, 2011. 192p.

CARRASCO, C. La economía feminist: rupture teórica y propuesta política. In: CARRASCO, C. Con voz propia: la economía feminista como apuesta teórica y política. Madrid: La Oveja Roja, 2014. p.25-47.

FAO. The state of food and agriculture: livestock in the balance. Rome: FAO, 2009. 180p.

FAO. The state of food and agriculture: women in agriculture closing the gender gap for development. Rome: FAO, 2011. 160p.

FERREIRA, A.P.L.; MATTOS, L.C. Convergências e divergências entre feminismo e agroecologia. Ciência e Cultura, v.69, n.2, p.38-43, 2017. Available from: <http:// cienciaecultura.bvs.br/scielo.php?script $=$ sci_arttext\&pid $=$ S0009-67252017000200013 $>$. Accessed: Feb. 08, 2019. doi: $10.21800 / 2317-66602017000200013$.

HEREDIA, B.M.A.; CINTRÃO, R.P. Gênero e acesso a políticas públicas no meio rural brasileiro. Revista Nera, v.9, n.8, p.1-28, 2006. Available from: <http://www.mstemdados.org/sites/default files/1443-4191-1-PB.PDF>. Accessed: Feb. 08, 2019.

KERGOAT, D. A relação social de sexo: da reprodução das relações sociais à sua subversão. Pro-Posições, v.13, n.1, p.47-59, 2002. Available from: $<$ https://periodicos.sbu.unicamp.br/ojs/index.php/ proposic/article/view/8643968>. Accessed: Feb. 08, 2019.

LOPES NETO, A.A.; et al. Caderneta agroecológica empoderando mulheres, fortalecendo a agroecologia. Revista Agriculturas, v.12, n.4, p.43-47, 2015. Available from: <http://aspta.org.br/wpcontent/uploads/2016/04/Agriculturas_V12N45-Artigo7.pdf $>$. Accessed: Feb. 08, 2019.

MINAYO, M. C. S. O desafio do conhecimento: pesquisa qualitativa em saúde. São Paulo: Hucitec, 2010. 407p.
MUÑOZ, L. G. Mujeres y crisis: un análisis feminista de la gran recesión y el austericidio. In: CARRASCO, C. Con voz propia: la economía feminista como apuesta teórica y política. Madrid: La Oveja Roja, 2014. p.193-217.

NOBRE, M. Igualdade para todas: estratégias para políticas públicas e açõesdomovimento. RevistaEstudosFeministas, v.24,n.2,p.645-652, 2016. Available from: $<$ http://www.scielo.br/scielo.php?pid=S0104026X2016000200645\&script $=$ sci abstract\&tlng=pt $>$. Accessed: Feb. 09, 2019. doi: 10.1590/1805-9584-2016v24n2p645.

PACHECO, M. E. L. Os caminhos das mudanças na construção da agroecologia pelas mulheres. Revista Agriculturas, v.6, n.4, p.4-8, 2009. Available from: $<$ https://ideiasnamesa.unb.br/upload/bibliotec aIdeias/26062015095654Os-caminhos-das-mudancas-na-construcaoda-Agroecologia-pelas-mulheres.pdf > . Accessed: Feb. 08, 2019.

PAULILO, M.G.S. Trabalho familiar: uma categoria esquecida de análise. Estudos Feministas, v.12, n.1. p.229-252, 2004. Available from: <https://periodicos.ufsc.br/index.php/ref/article/ view/S0104-026X2004000100012/8696>. Accessed: Feb. 08, 2019. doi: 10.1590/S0104-026X2004000100012.

SALES; C.M.V. Mulheres rurais: tecendo novas relações reconhecendo direitos. Estudos Feministas, v.15, n.2, p.437-443, 2007. Available from: <https://periodicos.ufsc.br/index.php/ref/ article/view/S0104-026X2007000200010>. Accessed: Feb. 08, 2019. doi: 10.1590/S0104-026X2007000200010.

SALES, M.N.G. Pequenas criações nos sistemas produtivos familiares: a diversidade na unidade. Revista Agriculturas, v.2, n.4, p.4-6, 2005. Available from: <http://aspta.org.br/wp-content/ uploads/2011/05/Agriculturas v2n4.pdf>. Accessed: Feb. 08, 2019.

SALVARO, G.I.J.; LAGO, M.C.S.; WOLFF, C.S. "Mulheres agricultoras" e "mulheres camponesas": lutas de gênero, identidades políticas e subjetividades. Psicologia \& Sociedade, v.25, n.1, p.79-89, 2013. Available from: $<\mathrm{http}: / / \mathrm{www} . \mathrm{scielo} . \mathrm{br} / \mathrm{pdf} / \mathrm{psoc} / \mathrm{v} 25 \mathrm{n} 1 / 10 . \mathrm{pdf}>$. Accessed: Feb. 10, 2019. doi: 10.1590/S0102-71822013000100010.

SANTOS, P.A.; BEVILACQUA, P.D. Family farming in agroecological transition: a look at the marketing of milk and dairy products in municipalities of the Zona da Mata of Minas Gerais State, Brazil. Ciência Rural, v.49, n.7, 2019. Available from: $<$ http://www.scielo.br/scielo.php?script=sci_arttext\&pid=S010384782019000700931\&lng=en\&nrm=iso >. Accessed: Jul. 17, 2019. doi: 10.1590/0103-8478cr20180299.

SILIPRANDI, E. Mulheres e agroecologia: transformando o campo, as florestas e as pessoas. Rio de Janeiro: Editora UFRJ, 2015. 352p.

SILIPRANDI, E. Reflexiones teóricas sobre un enfoque feminista en la agroecología. Cadernos de Agroecologia, v.13, n.1, 2018. Available from: <http://cadernos.aba-agroecologia.org.br/index. php/cadernos/article/view/562/846>. Accessed: Mar. 12, 2019.

SILIPRANDI, E. O que se pensa, o que se faz, o que se diz: discursos sobre as mulheres rurais. Educação em Debate, v.2, n.44, p.106-110, 2002. Available from: <http://www.repositorio ufc.br/bitstream/riufc/15156/1/2002_art_esiliprandi.pdf $>$. Accessed: Mar. 12, 2019.

SILVA, J.F. A mulher como força de trabalho na modernização da agricultura no Brasil. Revista Latino-Americana de História, v.1, n.3, p.232-248, 2012. Available from: <http://projeto.unisinos. br/rla/index.php/rla/article/view/81/59>. Accessed: Feb. 10, 2019. 